\title{
Local Residents' Perception about Tourism and Foreign Residents: a Spanish Case
}

\section{Study}

\begin{abstract}
It is important to learn about local residents' perceptions in relation to tourism and the presence of tourists who eventually become foreign residents, since tourism development is bound to have consequences of an economic, sociocultural and environmental nature. This paper has collected quantitative as well as qualitative information in order to analyze those effects in the case of a tourism destination located on the Costa Blanca (Spain). The impact of tourism development is additionally associated with local residents' satisfaction with their municipality. According to the conclusion reached, a connection exists between that satisfaction amongst local residents and the availability of new business opportunities, the development and maintenance of good relationships between local residents, foreign residents and tourists, and the international atmosphere which arises as a result.
\end{abstract}

Keywords: local residents, foreign residents, residential tourism, residents' perception, satisfaction.

\section{INTRODUCTION}

The relationships between tourists, foreign residents and the local population often face numerous problems. Furthermore, ignoring residential -or second-home- tourism would mean leaving aside an important explanation of travel and tourism infrastructure behavior (Back, 2019; Müller, 2006; Honkanen, Pitkänen \& Hall, 2016); hence our interest to learn 
more about local residents' attitudes with regard to tourism as a whole and, more specifically, concerning residential tourism.

Although the factors influencing residents' perception about tourism have been extensively investigated, it becomes necessary to replicate studies in various locations and at different points in time (D'Mello et al., 2015). Furthermore, a large number of these works have focused on North America and, to a much lesser extent, on other world regions such as Australia, New Zealand or the United Kingdom. In comparison, the Mediterranean area has received far less attention (Sharpley, 2014).

That is why our paper places the emphasis on examining the perceptions that the local residents of a small tourist town located on the Costa Blanca (Spain) have when it comes to the presence of tourists and foreign residents in their municipality. A link arises in our research between that perception and the level of satisfaction identified amongst local residents with their own town. This study explains the results obtained through a combination of quantitative and qualitative data. Our ultimate purpose consists in offering ideas and recommendations meant to ensure that local residents feel satisfied and maintain their quality of life despite the development of tourism in their hometown.

The following pages are going to offer a review of the literature dedicated to local residents' perception about tourism, the factors which moderate such perceptions, the peculiar characteristics of residential tourism, and the role of satisfaction as a measure to assess the views of local residents concerning tourism. Some data will subsequently be supplied about the specific town around which this particular study revolves, additionally describing its methodology, the findings derived from the fieldwork carried out, and the conclusions drawn.

\section{LITERATURE REVIEW}

\subsubsection{LOCAL RESIDENTS' PERCEPTION ABOUT TOURISM}


Reviewing the literature dedicated to examining the effects of tourism on local residents allows us to check that those effects may be both positive and negative, and that they relate to economic, sociocultural and/or environmental aspects.

Positive economic effects. Tourism means greater employment opportunities and higher revenues for a town (Tosun, 2002). Tourism not only gives a boost to businesses and the local economy but also generates more taxes that provide more revenues to the public coffers. Those revenues may in turn help improve public services such as healthcare or public safety, and even enhance public infrastructures which are enjoyed by locals and tourists alike (Deery, Jago \& Fredline, 2012; Gursoy \& Rutherford, 2004).

Rural communities can not only improve the services typically associated with tourism (accommodation, catering, leisure...) but also favor traditional economic activities such as agriculture, cattle raising, gastronomy or local arts and crafts. After all, tourists sometimes seek the authentic and most original features of those communities (Spielmann, Babin \& Manthiou, 2018; Spielman, Rasoolimanesh et al., 2017; Hao, Long \& Kleckley, 2011; Kim, Uysal \& Sirgy, 2013).

Positive sociocultural effects. Tourism is likely to generate social or cultural benefits (Látkova \& Vogt, 2012). On the one hand, it can widen the range of potential activities performed in a city; tourism will thus most probably improve leisure, recreation and shopping centers, simultaneously increasing the number of festivals and the chances to enjoy outdoor leisure — such services and events always experience growth in popular tourism destinations (Andereck et al., 2007; Brunt \& Courtney, 1999; Deery, Jago \& Fredline, 2012). The chances to socialize and to enjoy a higher level of cultural interaction consequently increase. Tourism can help build a friendly community; it favors the exchange of ideas by encouraging people's desire to be part of the community and, 
therefore, enriches cultural life (Gursoy \& Rutherford, 2004; Su \& Wall, 2014; Soszyński, et al., 2018).

Finally, tourism has a potential to enhance the sense of pride about a town (Jimura, 2011), which comes to be seen as a place worth visiting because of its natural and historical attractions, as well as those related to leisure (Schofield, 2011).

Positive environmental effects. Even though tourism generates revenues which make environmental improvement and conservation tasks easier (Látkova \& Vogt, 2012), as shown below, the literature has usually paid more attention to its negative repercussions than to the positive ones.

Negative economic effects. The presence of tourism implies that more people demand public services, not only local residents but also tourists. This not only forces the public coffers to assume a higher maintenance-related expenditure in such areas as beaches, parks and roads but also implies greater needs as far as public transport is concerned (Deery, Jago \& Fredline, 2012).

The most serious economic problems come with the rise of prices for products in general and, particularly, for housing. Tourism can actually lead to such high housing prices that it might end up displacing local residents (Tovar \& Lockwood, 2008).

Negative social effects. Except for business travelers, tourists are enjoying their leisure time while local residents are simultaneously developing their working and everyday life. This causes multiple interruptions and interferences between both groups (Honkanen, Pitkänen \& Hall, 2016). A larger number of individuals demand the same services (healthcare, leisure, transport, etc.), which results in annoying concentrations of people in public places, a lower likelihood of finding spaces to park, traffic problems, noise and overcrowding (Gursoy \& Rutherford, 2004; Gursoy, Chi \& Dyer; 2010; Gursoy, Jurowsky \& Uysal, 2002; Mantecón \& Huete, 2011). 
On some occasions, tourists change their personality so much that they can show undesired behaviors, provoking an increasingly visible presence of problems such as alcohol or drug abuse, gambling, betting, fraud or theft, and even promoting the development of prostitution (Deery, Jago \& Fredline, 2012; Tosun, 2002).

Negative environmental effects. Tourism undeniably has negative effects too, including ecological damage, water contamination and air pollution, amongst others (Rasoolimanesh et al. 2017; Hao, Long \& Kleckley, 2011; Schofield, 2011). Tourism is likely to affect the conservation and appreciation of natural areas; it can cause problems related to the preservation of wildlife and change the appearance of a local area to a great extent, increasing the volume of waste, generating noise pollution, and favoring an excessive and clearly unsustainable use of natural resources (Deery, Jago \& Fredline, 2012; Tovar \& Lockwood, 2008). Land speculation leads to transform natural areas into building development zones, due to the growing demand for dwellings and other infrastructures for tourist purposes.

This balance between positive and negative effects will make local residents have a good or a bad perception about tourism depending on whether it helps improve their community or it represents a source of unwanted competition for their resources — which prevents them from using those resources and ultimately contributes to their degradation(Jurowski, Uysal \& Williams, 1997).

\subsection{FACTORS INFLUENCING THE PERCEPTION ABOUT TOURISM}

Not every local resident has the same perception and attitude toward tourism. It will all depend on intrinsic factors such as personality, as well as on the characteristics inherent 
to tourism development. A literature review allows us to identify a variety of factors which determine the views of locals about tourism (Table 1).

INSERT TABLE 1

The term Intrinsic Factors used in Table 1 describes those most closely related to the local resident's own characteristics, as opposed to Extrinsic Factors -external to residents' individual features.

Intrinsic Factors. Contradictory results have been found about the extent to which sociodemographic characteristics influence the perception about tourism. By way of example, according to Honkanen et al. (2016), women in general and individuals with a higher educational level — regardless of their sex - are the best predisposed to accept foreigners; Wang and Pfister (2008) checked that women see tourism positively because more cultural activities are organized thanks to it. Andriotis and Vaughan (2003), along with Schofield (2011), also found a link between educational level and the attitude toward tourism, and Almeida-García et al. (2016) and Alrwajfah, Almeida-García and CortésMacías (2019) reached the conclusion that, unlike sex, age and educational level do influence views about tourists. Instead, Haley, Santih and Miller (2005) argued that neither age nor sex have any bearing on the attitudes toward tourism. D'Mello et al. (2015), Rasoolimanesh et al. (2015) and Látkova and Vogt (2012), as well as Tovar and Lockwood (2008), also studied the extent to which age or educational level influence the perception about tourism. As for ethnicity, Andereck et al. (2007) came to the conclusion that Hispanic individuals have a more positive view about the effects of tourism than those of Anglo-Saxon origin. It is also worth highlighting from another perspective that Rasoolimanesh et al. (2015) and Gursoy and Rutherford (2004) described the most strongly attached inhabitants as those who usually have a more positive view about tourism development. 
Needless to say, the greater or lesser dependence on the tourism sector as well as their degree of involvement therein will make locals show more or less favorable attitudes in this regard (Andriotis \& Vaughan, 2003). Thus, Cawler and Gillmor (2008) concluded that, while residents who are entrepreneurs tend to prioritize the financial profits stemming from tourism development, the rest of the community places the emphasis on non-economic aspects.

Extrinsic Factors. The existence of a cultural gap between tourists and locals will most probably trigger cultural conflicts as well as a negative attitude amongst local residents (Haobin Ye et al., 2014). For this reason, domestic tourists tend to be better received than international ones (Vargas-Sánchez, Porras-Bueno \& Plaza-Mejía, 2014). Along the same lines, the absence of a wealth gap between locals and tourists - together with a balanced distribution of the profits derived from tourism between locals and non-locals - will definitely lead to a more favorable attitude toward tourism too (Tosun, 2002).

As tourism gradually reaches an excessive degree of maturity and invades their everyday life, local residents start to become increasingly critical of its development (McGehee \& Andereck, 2004; Gilbert \& Clarck, 1997). This correlates with seasonality as well: the perceptions about tourism during the high season are clearly worse than those identified during the low season due to all the inconveniences for local residents that the presence of tourists entails (Vargas-Sánchez, Porras-Bueno \& Plaza-Mejía, 2014).

Some studies have also suggested that rural tourism is better regarded than urban tourism (Rasoolimanesh et al., 2017).

\subsection{RESIDENTIAL TOURISM}

Second home — or residential — tourists differ from others because they return to the same place year after year. Their strong emotional ties with that second home and with the town where it is located frequently make them become important local agents in those 
residential tourism locations (Honkanen, Pitkänen \& Hall, 2016). They are also different from other tourists because they travel neither to visit new places nor to meet new people, to which must be added that many of their activities are the same day-to-day activities (gardening, for instance) that they could perform in their first home too. For this reason, residential tourists' activities lie halfway between those carried out by tourists and the ones which are characteristic of the local community (Müller, 2002). In fact, many of them eventually become tourist immigrants, since their second home acquires the status of a main dwelling, and what was supposed to be a residential tourism destination ends up being chosen as their place of habitual residence (Bowen \& Schouten, 2008).

A large number of residential tourists are aged persons (Casado-Díaz, 1999) and there seems to be no stopping for this trend, favored by the higher longevity, the earlier retirement ages, the increased income, and the new lifestyles (Williams et al, 2000).

The town around which our study revolves shows an interesting combination of conventional tourism and large numbers of residential tourists.

\subsection{SATISFACTION AS A MEASURE}

Even though numerous works have focused on identifying local residents' views and attitudes about the impact of tourism in their communities, few studies have assessed the connections between tourism development and community satisfaction (Ko \& Steward, 2002). Satisfaction represents a valid measure of positive perceptions about tourism, though (Foroni, Modica \& Zenga, 2019; Alrwajfah, Almeida-García, \& Cortés-Macías, 2019). It is obviously a subjective measure which obviates other more objective variables such as economic, social, environmental or health-related welfare. Nonetheless, several authors, including Nunkoo and So (2016), Andereck et al. (2007), Andereck and Nyaupane (2011) or Kim, Uysal and Sirgy (2013) have actually used it. 
Along these same lines, our study will link the various perceptions about tourism to local residents' general level of satisfaction with their life in the municipality.

\section{METHODOLOGY}

The empirical study took place in Alfaz del Pi (Alicante province, Spain), a town located right in the heart of the Costa Blanca, on the Mediterranean coast. The current census of legal residents in Alfaz del Pi clearly shows the relevance acquired by foreign residents —a total of 12,691 (56.07\%), as opposed to 9,942 Spaniards (43.93\%) (González et al., 2017). In order of importance by nationalities, we can highlight those coming from the United Kingdom -with 3,292 residents (14.54\%)- and Norway -with 2,626 (11.6\%)even though the fluctuating population may reach ca. 8,000 people. The Netherlands with $7.7 \%$, Romania with $3.89 \%$, Germany with $2.9 \%$, and Belgium with $2.36 \%$ complete the group of countries with the highest numbers of residents in this town.

Our study combines quantitative and qualitative methods. Firstly, we carried out a survey amongst national residents trying to collect their views about Alfaz del Pi, in relation to tourism as a whole and, more precisely, concerning the significant presence of foreign residents in the municipality. The survey questionnaire -based on the literature review undertaken within the framework of this study- contains 3 questions about the interviewee's profile and one with a 1-to-7 Likert-type scale focused on the relevance that they assigned both to the tourism phenomenon in general and, more specifically, to the arrival of numerous foreign residents in Alfaz del Pi who eventually settle down there (see Appendix).

The survey was uploaded to the Alfaz del Pi town council's website, letting local residents' associations know about it, and requesting their collaboration to obtain responses. We collected a total of 107 valid responses in this way (during the period comprised between April and June 2017). The interviewee's profile appears in Table 2. 
As can be seen, most respondents were grown-ups (the mean, median and mode of this variable are 45.3, 45 and 43 years, respectively), the group being balanced in terms of gender too. A vast majority of interviewees has completed secondary education, with a high percentage of university graduates as well (42.1\% of survey respondents).

\section{INSERT TABLE 2}

As for the question with a Likert-type scale referring to local residents' perceptions about tourism and foreign residents, it consists of 15 items. The Cronbach's alpha value of 0.894 means that the scale is reliable.

Secondly, the qualitative analysis was structured around group meetings and in-depth open interviews with a wide variety of tourist agents based in Alfaz del Pi. For the purposes of this paper, our interest focuses on the interviews held with the presidents of MEMBA (Spanish initials for: 'Association for the development of female entrepreneurs from La Marina Baixa'), JOVEMPA (Spanish initials for: Federation of Associations of Young Entrepreneurs from La Marina Baixa), COEPA (Spanish initials for: Business Confederation of the Alicante Province), as well as with the managers of the Betanien Foundation (a geriatric center located in Alfaz del Pi and mostly financed by the town council of Bergen (Norway)) and the Mare Nostrum Forum (a residential complex for pensioners). All interviewees share a common feature: their first-hand knowledge of the experience as residents. Whereas a seventy-five-minute-long group meeting was carried out in the case of MEMBA, JOVEMPA and COEPA, the meetings with the Betanien Foundation and the Mare Nostrum Forum developed through semi-structured interviews which lasted about one hour each. Although quite a few goals were sought with these interviews, since our aim consisted in identifying the strengths and weaknesses of this municipality as a healthy tourism destination —along with the threats and opportunities associated with it - the most relevant results when it comes to understanding the extent 
to which local residents are satisfied with life in their town can be summarized in three issues, namely: Managing Multiculturality; Promoting Symbiosis; and Maintaining Quality of life.

\section{RESULTS}

\subsection{QUANTITATIVE RESULTS}

The outcomes derived from the quantitative analysis are presented first. Items in Table 3 show what local residents think of tourists and foreign residents (Table 3 providing the mean, the median and the mode of each item). The first striking aspect in this table is the high value that respondents assign to every one of the items proposed; as a matter of fact, modes (the most frequent value of each item) are invariably 7 -the highest possible value on this scale. In other words, all interviewees strongly agree with each statement proposed to them. It especially deserves to be highlighted that both foreign residents and tourists are educated individuals, and also that the presence of tourists and foreign residents not only implies new business opportunities for the municipality but also brings an international atmosphere.

\section{INSERT TABLE 3}

Amongst the least valued issues stands out the fact that tourists and foreign residents make housing prices increase and that the municipality would most probably experience financial problems were it not for tourism and foreign residents. It needs to be highlighted, though, that despite being the items with the lowest score, we must take them into consideration because their mean largely exceeds that of the Likert scale.

A key item stands out in this question, namely to know whether living in Alfaz del Pi satisfies the interviewees or not. The answers show that it does, since this item has a mean of 5.43 on a 1-to-7 scale, to which can be added that its median and its mode are 7 . 
A principal component factor analysis was subsequently carried out with the items corresponding to national residents' opinions about the presence of tourism and foreign residents in Alfaz del Pi. This analysis seeks to reduce the initial information offered by the original variables to a set of minor factors, thus highlighting the underlying factors or constructs in the information provided by the original items. It consequently becomes clear that performing a factor analysis represents a pertinent choice, since the correlation determinant matrix is close to zero (0.023), the Kaiser-Meyer-Olkin index lies between 0 and 1, and above 0.5 (0.744), and Bartlett's Sphericity Test is significant too (1026.747 and significance 0.000) (Bartlett, 1950).

A total of 4 eigenvalues higher than 1 appear after the implementation of the Principal Component Factor Analysis, which suggests the convenience of extracting four factors which explain $70.175 \%$ of the information supplied by the original variables (a satisfactory ratio, since it exceeds 50\%). A Varimax rotation helps achieve a better understanding of the factors involved, and Table 4 shows the resulting factors, together with the original items most present in their formation.

\section{INSERT TABLE 4}

The first factor will be given the name of Satisfaction because the most relevant item therein refers to the degree of satisfaction associated with living in Alfaz del Pi. This factor additionally has a visible connection with the items linked to new business opportunities stemming from tourism and from the presence of foreign residents, to the good relationships with tourists and residents, and to the international atmosphere created by tourists and foreign residents. This factor stands out as the most important of all —it accounts for $25 \%$ of total variance in this analysis alone.

The second factor, labelled as Economic Factors, refers to the possibility of housing prices rising or being maintained due to the presence of tourism and foreign residents, as 
well as to the fact that the absence of tourists or foreign residents might entail financial difficulties for the town. This is the second most important factor, since it explains $17 \%$ of total variance in the analysis.

The term Non-Interference — chosen for the third factor- stresses that tourists and foreign residents do not or hardly interfere with national residents' everyday life, the fourth and final factor being called A Good Educational Level because it shows that tourists and foreign residents tend to be educated individuals. These last two factors have a similar weight, more precisely, $15 \%$ each -slightly below the second one in variance formation.

After obtaining the four factors mentioned above, we asked ourselves whether they are more or less important for the different interviewee profiles, for which purpose the mean equality test shown in Table 5 proved useful. Student's T and Anova parametric tests were applied, and Mann-Whitney's U or Kruskal-Wallis non-parametric ones in the absence of homoscedasticity. Such tests enabled us to find out that all factors score similarly regarding age, without any significant mean differences. However, the factor related to Satisfaction obtains the highest scores amongst women, the Good Educational Level of foreign residents and tourists being valued above all by university graduates.

\section{INSERT TABLE 5}

\subsection{QUALITATIVE RESULTS}

As for qualitative results, how has this town succeeded in making its local residents feel satisfied with their life there? First and foremost, through a suitable management of multiculturality. According to our interviewees' comments, a good level of integration exists between the different nationalities that live together in this municipality. This integration seems far more evident amongst youngsters than amongst older people, though, since the latter came to become residents or to go sightseeing at a senior age - 
being already retired. It also becomes evident that, despite having lived in Alfaz del Pi for many years, a large proportion of foreign residents spoke no Spanish. In any case, this circumstance does not cause them much trouble, thanks to the availability of private services, e.g. shops or medical centers, where they can be attended to in their own language, along with associations of a cultural nature, promoted by the foreign residents themselves both to develop social events which are traditional in their country of origin and to achieve their integration into the local community.

Alfaz del Pi boasts a large network of cultural associations (González et al., 2017), 6 of which are foreigners' associations (Dutch, Norwegian or French). Nonetheless, as pointed out by our respondents, the Town Council encourages an improved coordination between associations, as well as the development of cultural, social and environmental activities aimed at all residents, regardless of their nationality. By way of example, the town council has organized an International Day of the Municipality since 2007, and one of the local departments is mainly dedicated to relationships with residents of foreign origin.

In other words, foreign residents are looked after both privately and publicly, which creates an international ambiance thanks to which more foreign tourists can be attracted. And this does not annoy local residents at all. Quite the opposite, it improves the mutual relationships between locals and foreigners because, as revealed by the survey answers, local residents feel proud to see that their town is considered a welcoming place for everyone -thus matching the outcome of the study undertaken by Schofield (2011). Every respondent stresses the fact that you can lead a very good life in Alfaz del Pi and that an atmosphere of harmony reigns there. The municipality as such is multicultural and interviewees describe it as a 'little Europe.'

As regards the so-called Symbiosis, this term serves to define the mutual benefits that locals, residents, and tourists obtain from sharing their life in this town. According to the 
Social Exchange Theory (Stylidis et al., 2014, Andereck et al., 2005), when the advantages of tourism outnumber its drawbacks, a positive perception about tourism arises which increases the feeling of satisfaction with the town. The reality of Alfaz del Pi municipality shows that relationships are more complex, though; a symbiosis exists between tourists, foreign residents, and local residents, because they all benefit to a certain extent from coexisting with one another.

On the one hand, respondents tell us that some of the foreign tourists eventually realize that they like this place to spend long periods, which leads them to stop being occasional tourists and to become temporary residents through the rental of apartments, or in a more definitive way, by purchasing a dwelling. This decision most commonly takes place amongst couples formed by 50-to-60-year-old pre-retired foreigners who decide to build their own house so that they can come to live in the town for long periods. Later on, when these same residents reach the age of 70 , they start to harbor doubts about their health, about the need to socialize with people who find themselves in a situation similar to theirs, or about security in their houses, but they do not think about the possibility of returning to their countries of origin. It is then that they join the local foreigners' associations.

This highly interesting concept revolves around accompanying tourists during several stages of their life until they become residents and even decide to live at an old age home. Ties are thus built between the initial tourists and the environment, insofar as the former need a variety of services throughout the different stages of their life in the municipality. This transformation from being tourists to becoming residents brings about a deseasonalization of the tourism sector which has naturally occurred in this town for over 50 years - a model that entails a change of mindset amongst the local population in relation to tourists and foreign residents. As one respondent told us: "These foreigners 
have been my schoolmates, and my workmates too; as far as I am concerned, they are not foreigners, they are my friends."

One of our female interviewees referred to a curious phenomenon which happens at the old age home: according to the residents living there, their children visit them more often than they would if these seniors lived in their country of origin. This is so because they take advantage of visiting their parents to go sightseeing in the area as well, which in turn contributes to the creation of ties between residents (and their families) and the town.

Nevertheless, there are not only senior foreign residents in Alfaz del Pi, but also young people, with children, who work for third-age services, teach at Nordic schools and develop their activity in the whole service sector; i.e. they deliver services to hotels and houses, to foreign residents and tourists. Added to this, and likewise attracted by the appeal of this area and its surroundings, some families with a spouse working at oil rigs in Norway choose Alfaz del Pi as their habitual place of residence or to spend long periods of time there every year.

Our interviewees explained to us that quite a few tourists are several generations who share the same dwelling and occupy it at different times of year. Whereas the parents, already retired, live in it during the coldest months, attracted by the mild temperatures enjoyed in this town - compared to their country of origin - the children and grandchildren come during their holidays, in summer for instance. And very often, the multicultural atmosphere as well as the charm that characterizes this area captures them, eventually making them become usual tourists, and subsequently residents.

Such a variety of foreign tourists and residents provide local residents with work opportunities, together with numerous economic connections. The international ambiance created by all those foreigners is also enjoyed by local residents, who find it very attractive. 
As regards maintaining Quality of Life, Alfaz del Pi has managed to preserve welfare for local residents despite - or even thanks to- the presence of foreign tourists and residents. A part of that welfare is due to the town's intrinsic characteristics, including its Mediterranean climate, its location between the sea -with a blue-flag beach and breathtaking views- and the mountain -with Sierra Helada Natural Park. Such intrinsic features basically have to do with the natural resources available to local and foreign residents, who share them with tourists too.

Other extrinsic features undoubtedly exist, though: factors linked to the management -or lack of management - of the aforesaid natural resources. We would also like to highlight the tranquility that prevails in this area, the absence of large crowds, together with the maintenance and preservation of natural resources. Every single respondent stresses the "quiet, calm, and laid-back" atmosphere that characterizes life in Alfaz del Pi. The arrival of tourists neither causes overcrowding nor destroys tranquility, since the focus is placed on tourists or residents with a medium or high purchasing power. As rightly pointed out by interviewees, "Tourists seek tranquility in Alfaz del Pi; however, if they want a more bustling environment, they can have it in no time; the neighboring towns are very near, only a few minutes' drive away." Another interviewee emphasized the following: "Bosses spend their holidays in Alfaz del Pi, workers spend theirs in the nearby towns," referring to the average purchasing power of this town's tourists as opposed to that of those who visit other locations on the Costa Blanca.

In an attempt to escape from its categorization as a high-purchasing-power-tourism area, Alfaz del Pi has also been trying to specialize in sports tourism during the last few years (targeting — according to the interviewees — sportspeople looking for a winter shelter in the Mediterranean or for amateur sporting competitions which draw a larger audience of relatives and followers). Our respondents insist that the town's charm not only remains 
thanks to the absence of overcrowding in general but also because taxes make it possible both to improve public services and to maintain the beauty of the natural environs. They highlight the fitting-out of the Camino del Faro del Albir as a leisure space for locals and tourists alike in this respect.

One factor mentioned by respondents which needs to be highlighted is the local essence of this small international tourism destination which, despite its growing importance, has managed not only to keep its roots but also to successfully mix multiculturality with its most popular traditions. Evidence thereof is provided by the variety of local festivities that the interviewees referred to. Examples of these festivities are those in honor of the Santísimo Cristo celebrated in November, La Creueta in May, and La Purísima in December - these three markedly religious festivities bring religious events together with others of a social, playful and sporting nature. The end-of-summer festivities exclusively focus on fun and social aspects instead. All these activities help preserve old customs and ensure that locals will not feel like aliens in their own land; they can easily combine their festivities and traditions with a multicultural reality. The maintenance of local residents' social identity (Haobin Ye et al., 2014) therefore emerges as a highly relevant factor when it comes to explaining positive attitudes toward tourists and foreign residents.

\section{DISCUSSION AND CONCLUSION}

Analyzing local residents' perceptions about tourism becomes crucial to make sure that they feel satisfied with their own town as well as to develop a sustainable kind of tourism (Foroni, Modica \& Zenga, 2019). Our study shows how a small international tourist site has remained a cozy town where its native inhabitants are still happy to live. Satisfaction is linked here to the new business opportunities brought by tourism, to the good relationships existing between local inhabitants, foreign residents, and tourists, and even 
to the resulting international atmosphere. Merely economic factors such as the impact of tourism on housing prices or the financial difficulties that the municipality would go through in the absence of tourism have less weight in our study than the actual satisfaction associated with living Alfaz del Pi.

Residents especially appreciate the international ambiance-clearly beneficial to the town- and the fact that both tourists and international residents tend to have a good educational level; hence our decision to assign as much or even more importance to cultural factors than to economic ones. Our work thus follows Tovar and Lockwood (2008), who identified the availability of interesting things to do as the most favorable impact of tourism, rather than the merely economic benefits.

Our findings suggest that women are the most satisfied with the municipality, and also that the better educated interviewees value the good educational level of residents as well as tourists to a greater extent. This result is in keeping with previous works according to which women and better educated individuals tend to have a greater predisposition to accept the presence of foreigners (Honkanen, Pitkänen \& Hall, 2016).

Our research shows that the town under study has taken important steps to manage multiculturality, even if older foreign residents hardly make any efforts to integrate into Spanish society, since they feel at ease living inside a 'colony'; neither foreign residents nor tourists are seen as a nuisance by local residents. This result matches those obtained in previous studies about the impact of second-home tourism (Back, 2019). Younger foreign residents do make an effort to fit into the local society and culturally enrich schools or work centers, though. And public authorities equally promote cultural integration with festive events like the International Day, a celebration which tries to bring together all the residents in this town, in contrast with different kinds of festivities —e.g. the Native's Day_ proposed in other studies (Almeida-García et al. 2016). Our 
findings are in tune with previous research works (Soszyński et al., 2018) which show the potential benefits that local residents can draw from the interaction with tourists and foreign residents, as well as from the creation of shared living and enjoyment spaces.

Alfaz del Pi has additionally witnessed the aforesaid evolution from tourists to residents (Haug, Dann \& Mehmetoglu, 2007; Bowen \& Schouten, 2008; Brunt \& Courtney, 1999; Casado-Diaz, 1999), also showing how such a transformation must be accompanied by services able to meet the new demands of these evolving tourists.

Unlike what other studies suggest (Hao, Long \& Kleckley, 2011), the attitude of local residents in Alfaz del Pi arguably remains favorable to tourism and foreign residents, even though it has already become a mature destination. Below can be found some reasons why living in this destination still satisfies its local residents:

- Multiculturality has been properly managed, without neglecting local and deep-rooted elements such as festivities and traditions.

- Quality of life has been maintained, reinvesting the income generated by tourism in public resources and services.

- A quiet local atmosphere has been preserved, avoiding mass tourism.

- A commitment is now being made to promote alternative and more exclusive types of tourism, amongst which stands out sports tourism.

The preceding reasons can be considered key determinants to achieve sustainable tourism —which includes culture- and environment-related heritage elements (Butler, 2019) — in the town under analysis.

One of the most important recommendations made in this work refers to the need to collect the local resident's point of view prior to undertaking any tourism development activity. This piece of advice is in tune with the suggestions made in previous research works (Foroni Foroni, Modica, \& Zenga, 2019). After all, the destination's economic, 
social, cultural and even environmental profile is going to be altered, and that will inevitably affect its residents' quality of life and satisfaction levels. The problems caused by tourism in communities may be alleviated if public and private bodies collaborate to jointly develop tourism, so that the competing needs of natural spaces and tourism enterprises can be satisfactorily met (Jaafar, Rasoolimanesh \& Lonik, 2015). Those residents who are likely to be influenced by tourism projects, both financially or environmentally and in terms of social costs, should be empowered in tourism planning, thus favoring more democratic decision-making processes (Zhang, Cole \& Chancellor, 2013; Harrill, 2004). Apart from fostering destination sustainability in this way, we need local residents to have a positive perception about tourism for practical reasons. A hostile attitude of residents toward tourists may eventually become counterproductive for tourism; instead, friendliness will most probably help tourism development. Needless to say, tourists are usually reluctant to visit places where they feel unwelcome (AlmeidaGarcía et al., 2016). What is more, local residents play a critical role in the tourism system. In fact, if residents see tourism positively, they will become the best ambassadors of their communities and places of residence, through a word-of-mouth communication that can generate a favorable image of the place amongst potential visitors (San Martín et al., 2018).

Just like any other study, the present work has faced a number of limitations as well. On the one hand, the survey questionnaires were administered to a limited number of individuals who accessed them through the town council's website. Likewise, the interviews were made with people involved in the business world who may have directly or indirectly benefited both from tourist activities and from the presence of foreign residents. Nevertheless, in our view, the combination of results derived from quantitative and qualitative information provide enough evidence about the real situation of local 
residents in Alfaz del Pi. Furthermore, as highlighted by Tosun (2002), it is far from easy to elaborate a general theory from individual cases when dealing with local residents' perceptions about tourism.

To conclude, the present study fills a gap in the literature because, despite Spain's status as an essentially tourism-oriented country, not many works dedicated to analyzing the attitude shown by local residents toward tourism have been published so far. This research work has the peculiarity of studying local residents' perceptions about tourism and about foreign residents at the same time, through quantitative and qualitative analysis. Residents' perceptions about tourism must be taken into account because their opinion is necessary to develop and maintain sustainable tourism. And more importantly, our study shows some of the clues for an international tourist destination to remain satisfactory for its local residents: managing multiculturality without sacrificing the intrinsic local characteristics; maintaining quality of life to achieve residents' satisfaction; avoiding or stopping mass tourism; and promoting alternative and more exclusive types of tourism.

\section{REFERENCES}

Almeida-García, F., Peláez-Fernández, M. Á., Balbuena-Vázquez, A., \& Cortés-Macias, R. (2016). Residents' perceptions of tourism development in Benalmádena (Spain). Tourism Management, 54, 259-274.

Alrwajfah, M. M., Almeida-García, F., \& Cortés-Macías, R. (2019). Residents' Perceptions and Satisfaction toward Tourism Development: A Case Study of Petra Region, Jordan. Sustainability, 11(7), 1907.

Andereck, K. L., \& Nyaupane, G. P. (2011). Exploring the nature of tourism and quality of life perceptions among residents. Journal of Travel Research, 50(3), 248-260. 
Andereck, K. L., Valentine, K. M., Knopf, R. C., \& Vogt, C. A. (2005). Residents' perceptions of community tourism impacts. Annals of Tourism Research, 32(4), 10561076.

Andereck, K. L., Valentine, K. M., Vogt, C. A., \& Knopf, R. C. (2007). A cross-cultural analysis of tourism and quality of life perceptions. Journal of Sustainable Tourism, 15(5), 483-502.

Andriotis, K., \& Vaughan, R. D. (2003). Urban residents' attitudes toward tourism development: The case of Crete. Journal of Travel Research, 42(2), 172-185.

Back, A. (2019). Temporary resident evil? Managing diverse impacts of second-home tourism. Current Issues in Tourism, Article in press. DOI: $10.1080 / 13683500.2019 .1622656$

Bartlett, M. S. (1950). Tests of significance in factor analysis. British Journal of Statistical Psychology. 3(2), pp. 77-85.

Bowen, D., \& Schouten, A. F. (2008). Tourist satisfaction and beyond: tourist migrants in Mallorca. International Journal of Tourism Research, 10(2), 141-153.

Brunt, P., \& Courtney, P. (1999). Host perceptions of sociocultural impacts. Annals of Tourism Research, 26(3), 493-515.

Butler, R. W. (2019). Contributions of tourism to destination sustainability: golf tourism in St. Andrews, Scotland. Tourism Review, 74(2), 235-245.

Casado-Diaz, M. A. (1999). Socio-demographic impacts of residential tourism: a case study of Torrevieja, Spain. International Journal of Tourism Research, 1(4), 223.

Cawley, M., \& Gillmor, D. A. (2008). Integrated rural tourism: Concepts and Practice. Annals of Tourism Research, 35(2), 316-337. 
D’Mello, C., Chang, L-C., Kamat, K., Scaglione, M., Weiermair, K., \& Pillai, S.K.B. (2015). An examination of factors influencing residents' perception about the impacts of tourism in Goa. International Journal of Hospitality and Tourism Systems, 8(2), 1-12.

Deery, M., Jago, L., \& Fredline, L. (2012). Rethinking social impacts of tourism research: A new research agenda. Tourism Management, 33(1), 64-73.

Diputación de Alicante (2016) Documentación Gesdata. Internet Document. http://documentacion.diputacionalicante.es/8turismo.asp?codigo $=03011$

Foroni, I., Modica, P., \& Zenga, M. (2019). Residents' Satisfaction with Tourism and the European Tourism Indicator System in South Sardinia. Sustainability, 11(8), 2243.

Gilbert, D., \& Clark, M. (1997). An exploratory examination of urban tourism impact, with reference to residents' attitudes, in the cities of Canterbury and Guildford. Cities, 14(6), 343-352.

González, R.; Monllor, F.; Gascó, J., \& Llopis, J. (2017). L’Alfàs del Pi, Destino Saludable. (Alfaz del Pi, Healthy Destination). Internet Document. http://recs.es/wpcontent/uploads/2017/12/ESTUDIO-DE-LA-UNIVERSIDAD-DE-ALICANTE2017.pdf

Gursoy, D., \& Rutherford, D. G. (2004). Host attitudes toward tourism: An improved structural model. Annals of Tourism Research, 31(3), 495-516.

Gursoy, D., Chi, C. G., \& Dyer, P. (2010). Locals' attitudes toward mass and alternative tourism: The case of Sunshine Coast, Australia. Journal of Travel Research, 49(3), 381394.

Gursoy, D., Jurowski, C., \& Uysal, M. (2002). Resident attitudes: A structural modeling approach. Annals of Tourism Research, 29(1), 79-105.

Haley, A. J., Snaith, T., \& Miller, G. (2005). The social impacts of tourism a case study of Bath, UK. Annals of Tourism Research, 32(3), 647-668. 
Hao, H., Long, P., \& Kleckley, J. (2011). Factors predicting homeowners' attitudes toward tourism: A case of a coastal resort community. Journal of Travel research, 50(6), 627-640.

Haobin Ye, B., Qiu Zhang, H., Huawen Shen, J., \& Goh, C. (2014). Does social identity affect residents' attitude toward tourism development? An evidence from the relaxation of the Individual Visit Scheme. International Journal of Contemporary Hospitality Management, 26(6), 907-929.

Harrill, R. (2004). Residents' attitudes toward tourism development: A literature review with implications for tourism planning. Journal of Planning Literature, 18(3), 251-266. Haug, B., Dann, G. M., \& Mehmetoglu, M. (2007). Little Norway in Spain: From tourism to migration. Annals of Tourism Research, 34(1), 202-222.

Honkanen, A., Pitkänen, K., \& Hall, M. C. (2016). “A Local Perspective on Cross-Border Tourism. Russian Second Home Ownership in Eastern Finland." International Journal of Tourism Research, 18(2), 149-158.

Jaafar, M., \& Rasoolimanesh, S. M. \& Lonik, K.A.T. (2015). Tourism growth and entrepreneurship: Empirical analysis of development of rural highlands. Tourism Management Perspectives, 14, 17-24.

Jaafar, M., Noor, S. M., \& Rasoolimanesh, S. M. (2015). Perception of young local residents toward sustainable conservation programmes: A case study of the Lenggong World Cultural Heritage Site. Tourism Management, 48, 154-163.

Jimura, T. (2011). The impact of world heritage site designation on local communitiesA case study of Ogimachi, Shirakawa-mura, Japan. Tourism Management, 32(2), 288296.

Jurowski, C., Uysal, M., \& Williams, D. R. (1997). A theoretical analysis of host community resident reactions to tourism. Journal of Travel Research, 36(2), 3-11. 
Kim, K., Uysal, M., \& Sirgy, M. J. (2013). How does tourism in a community impact the quality of life of community residents? Tourism Management, 36, 527-540.

Ko, D. W., \& Stewart, W. P. (2002). A structural equation model of residents' attitudes for tourism development. Tourism management, 23(5), 521-530.

Látková, P., \& Vogt, C. A. (2012). Residents' attitudes toward existing and future tourism development in rural communities. Journal of Travel Research, 51(1), 50-67.

Mantecón, A., \& Huete, R. (2011). Sociological insights on residential tourism: host society attitudes in a mature destination. European Journal of Tourism Research, 4(2), 109.

McGehee, N. G., \& Andereck, K. L. (2004). Factors predicting rural residents'support of tourism. Journal of Travel Research, 43(2), 131-140.

Müller, D. K. (2002). Reinventing the countryside: German second-home owners in Southern Sweden. Current Issues in Tourism, 5(5), 426-446.

Müller, D. K. (2006). The attractiveness of second home areas in Sweden: A quantitative analysis. Current Issues in Tourism, 9(4-5), 335-350.

Nunkoo, R., \& So, K. K. F. (2016). Residents' support for tourism: Testing alternative structural models. Journal of Travel Research, 55(7), 847-861.

Rasoolimanesh, S. M., Jaafar, M., Kock, N., \& Ramayah, T. (2015). A revised framework of social exchange theory to investigate the factors influencing residents' perceptions. Tourism Management Perspectives, 16, 335-345.

Rasoolimanesh, S. M., Roldán, J. L., Jaafar, M., \& Ramayah, T. (2017). Factors influencing residents' perceptions toward tourism development: Differences across rural and urban world heritage sites. Journal of Travel Research, 56(6), 760-775. 
San Martín, H., García-de los Salmones, M. D. M., Herrero, Á., \& Pérez, A. (2018). Explaining residents' attitudes towards tourism and tourists: A new approach based on brand theory. International Journal of Tourism Research, 20(6), 738-747.

Schofield, P. (2011). City resident attitudes to proposed tourism development and its impacts on the community. International Journal of Tourism Research, 13(3), 218-233. Sharpley, R. (2014). Host perceptions of tourism: A review of the research. Tourism Management, 42, 37-49.

Soszyński, D., Sowińska-Świerkosz, B., Stokowski, P. A., \& Tucki, A. (2018). Spatial arrangements of tourist villages: implications for the integration of residents and tourists. Tourism Geographies, 20(5), 770-790.

Spielmann, N., Babin, B. J., \& Manthiou, A. (2018). Places as authentic consumption contexts. Psychology \& Marketing, 35(9), 652-665.

Stylidis, D., Biran, A., Sit, J., \& Szivas, E. M. (2014). Residents' support for tourism development: The role of residents' place image and perceived tourism impacts. Tourism Management, 45, 260-274.

Su, M. M., \& Wall, G. (2014). Community participation in tourism at a world heritage site: Mutianyu Great Wall, Beijing, China. International Journal of Tourism Research, 16(2), 146-156.

Tosun, C. (2002). Host perceptions of impacts: A comparative tourism study. Annals of Tourism Research, 29(1), 231-253.

Tovar, C., \& Lockwood, M. (2008). Social impacts of tourism: An Australian regional case study. International Journal of Tourism Research, 10(4), 365-378.

Vargas-Sánchez, A., Porras-Bueno, N., \& Plaza-Mejía, M. (2014). Residents' attitude to tourism and seasonality. Journal of Travel Research, 53(5), 581-596. 
Wang, Y., \& Pfister, R. E. (2008). Residents' attitudes toward tourism and perceived personal benefits in a rural community. Journal of Travel Research, 47(1), 84-93.

Williams, A. M., King, R., Warnes, A., \& Patterson, G. (2000). Tourism and international retirement migration: new forms of an old relationship in southern Europe. Tourism Geographies, 2(1), 28-49.

Zhang, Y., Cole, S. T., \& Chancellor, C. H. (2013). Residents' preferences for involvement in tourism development and influences from individual profiles. Tourism Planning \& Development, 10(3), 267-284. 
Table 1: Factors influencing the perception about tourism

\begin{tabular}{|l|ll|}
\hline Intrinsic & Extrinsic \\
\hline - $\begin{array}{l}\text { Sociodemographic characteristics (sex, age, } \\
\text { educational level, ethnicity) }\end{array}$ & $\circ \begin{array}{l}\text { Cultural gap between locals and tourists } \\
\text { (values, customs, language, etc.) }\end{array}$ \\
- Attachment to the community (number of \\
years as a resident, being native or not, owning
\end{tabular} \mid $\begin{aligned} & \text { National(Domestic)/Foreign tourism } \\
& \text { a dwelling or not, etc.) } \\
& \text { Involvement in the tourism sector }\end{aligned}$

Source: Own Elaboration

Table 2: Interviewee's Profile

\begin{tabular}{|l|l|r|}
\hline Age & Up to 40 & $32(29.9 \%)$ \\
& From 40 to 65 & $66(61.7 \%)$ \\
& Over 65 & $9(8.4 \%)$ \\
\hline Gender & Male & $53(49.5 \%)$ \\
& Female & $54(50.5 \%)$ \\
\hline Studies & Primary & $13(12.1 \%)$ \\
& Secondary & $49(45.8 \%)$ \\
& University & $45(42.1 \%)$ \\
\hline
\end{tabular}

Source: Own Elaboration

Table 3: Spanish residents, tourism and foreign residents

\begin{tabular}{|l|l|l|l|}
\hline Item & Mean & Median & Mode \\
\hline Educated Foreign Residents & 5.94 & 7 & 7 \\
\hline Tourists bringing New Opportunities & 5.86 & 7 & 7 \\
\hline Educated Tourists & 5.82 & 6 & 7 \\
\hline $\begin{array}{l}\text { Tourists providing an International } \\
\text { Ambiance }\end{array}$ & 5.74 & 7 & 7 \\
\hline $\begin{array}{l}\text { Foreign Residents providing an } \\
\text { International Ambiance }\end{array}$ & 5.67 & 7 & 7 \\
\hline $\begin{array}{l}\text { Foreign Residents bringing New } \\
\text { Opportunities }\end{array}$ & 5.59 & 7 & 7 \\
\hline Good Relationship with Tourists & 5.47 & 7 & 7 \\
\hline I am satisfied in Alfaz del Pi & 5.43 & 7 & 7 \\
\hline $\begin{array}{l}\text { Good Relationship with Foreign } \\
\text { Residents }\end{array}$ & 5.35 & 6 & 7 \\
\hline Foreign Residents do not Interfere & 4.99 & 6 & 7 \\
\hline Tourists do not Interfere & 4.92 & 6 & 7 \\
\hline Tourists increase Housing Prices & 4.57 & 5 & 7 \\
\hline $\begin{array}{l}\text { Financial difficulties without Foreign } \\
\text { Residents }\end{array}$ & 4.49 & 5 & 7 \\
\hline $\begin{array}{l}\text { Financial Difficulties without Foreign } \\
\text { Residents }\end{array}$ & 4.40 & 6 & 7 \\
\hline $\begin{array}{l}\text { Foreign Residents increase Housing } \\
\text { Prices }\end{array}$ & 4.36 & 5 & 7 \\
\hline Source: Own Elaboration & & 6 \\
\hline
\end{tabular}

Source: Own Elaboration 
Table 4: Total Variance Explained and Rotated Factor Matrix from the National Residents, Tourism, and Foreign Residents Factor Analysis

\begin{tabular}{|c|c|c|c|c|c|c|c|c|c|c|c|}
\hline \multicolumn{7}{|c|}{ Explained Total Variance } & \multicolumn{5}{|c|}{ Rotated Factor Matrix } \\
\hline & \multicolumn{3}{|c|}{ Initial Eigenvalues } & \multicolumn{3}{|c|}{$\begin{array}{l}\text { Rotation Sum of Squared } \\
\text { Loadings }\end{array}$} & \multirow[t]{2}{*}{ Variable } & \multicolumn{4}{|c|}{ Factor } \\
\hline Factor & Total & $\begin{array}{c}\% \text { of } \\
\text { Variance }\end{array}$ & $\begin{array}{c}\text { Cumulative } \\
\%\end{array}$ & Total & $\begin{array}{c}\% \text { of } \\
\text { Variance }\end{array}$ & $\begin{array}{c}\text { Cumulative } \\
\%\end{array}$ & & 1 & 2 & 3 & 4 \\
\hline 1 & 6.275 & 41.831 & 41.831 & 3.756 & 25.041 & 25.041 & Touris. New Opportuni. & 0.718 & 0.235 & 0.001 & 0.053 \\
\hline 2 & 2.044 & 13.629 & 55.460 & 2.577 & 17.180 & 42.221 & Foreig. Resi. New Opportuni. & 0.664 & 0.289 & 0.007 & 0.571 \\
\hline 3 & 1.432 & 9.549 & 65.009 & 2.292 & 15.279 & 57.500 & Good Relat. Touris. & 0.723 & 0.221 & 0.441 & 0.034 \\
\hline 5 & .825 & 5.498 & 78.178 & & & & Housing Price. Touris. & 0.168 & 0.829 & 0.054 & 0.240 \\
\hline 6 & .725 & 4.834 & 83.012 & & & & Housing Price. Foreig. Resi. & 0.106 & 0.830 & -0.016 & 0.244 \\
\hline 7 & .555 & 3.699 & 86.710 & & & & Financ. Difficult. Touris. & 0.265 & 0.670 & 0.374 & -0.040 \\
\hline 8 & .421 & 2.810 & 89.520 & & & & Foreig, Resi. Financ. Difficult. & -0.017 & 0.620 & 0.518 & 0.052 \\
\hline 9 & .374 & 2.493 & 92.013 & & & & Educated Touris. & 0.212 & 0.251 & 0.220 & 0.756 \\
\hline 10 & .339 & 2.262 & 94.275 & & & & Educated Foreig.Resi & 0.225 & 0.122 & 0.154 & 0.876 \\
\hline 11 & .251 & 1.677 & 95.951 & & & & Touris. Internat. Ambiance. & 0.753 & -0.018 & 0.049 & 0.400 \\
\hline 12 & .229 & 1.530 & 97.481 & & & & Foreig.Resi. Internat. Ambiance & 0.719 & -0.052 & 0.086 & 0.405 \\
\hline 14 & .113 & .756 & 99.489 & & & & Foreig.Resi. do Not Interfere & 0.141 & 0.098 & 0.875 & 0.212 \\
\hline 15 & .077 & .511 & 100.000 & & & & I am Satisfied & 0.756 & 0.028 & 0.200 & 0.314 \\
\hline
\end{tabular}

Source: Own Elaboration 
Table 5: Mean Equality Test for National Residents, Tourism, and Foreign Residents according to the Interviewees' different profiles

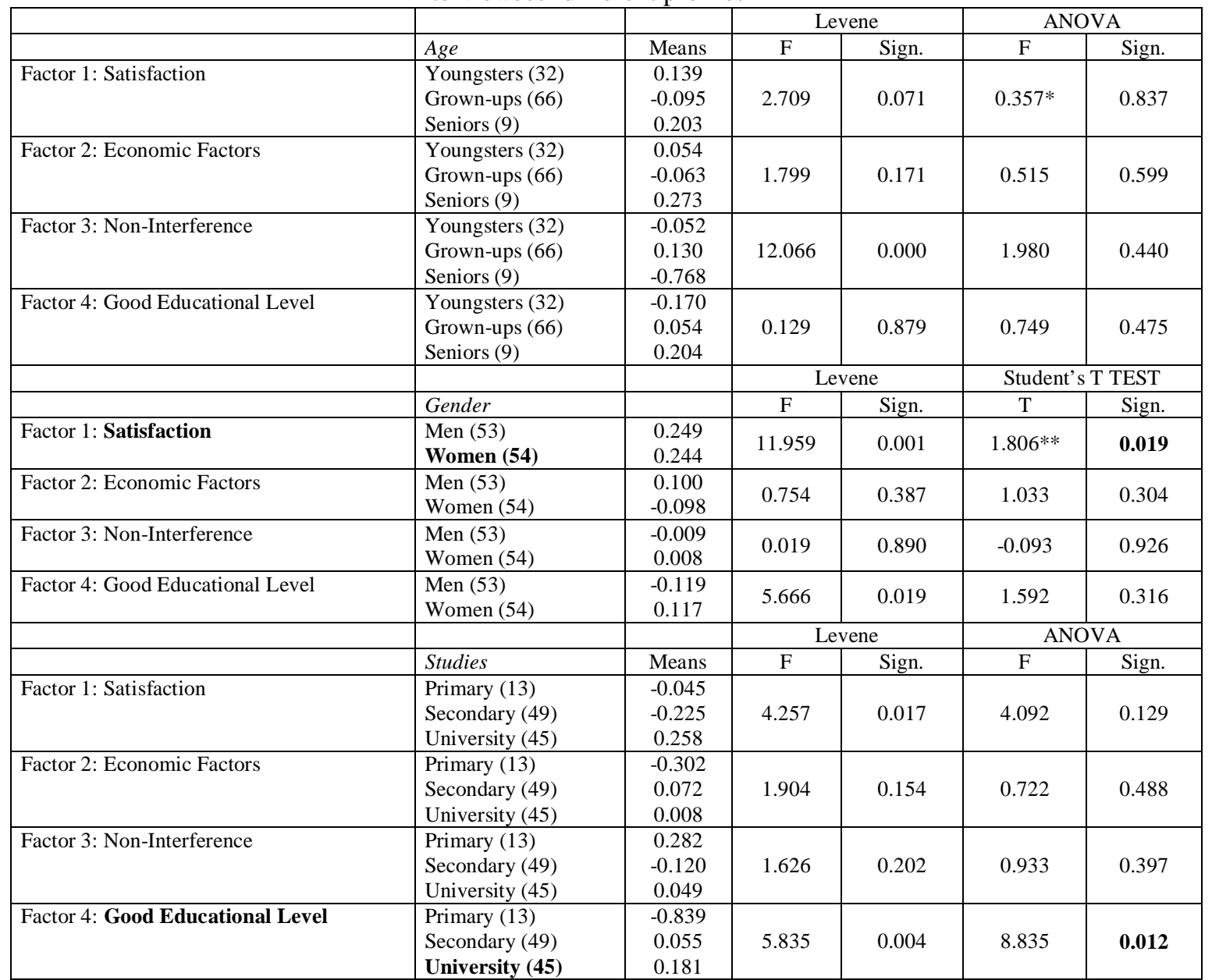

*Kruskal-Wallis Non-Parametric Test **M ann-Whitney's Non-Parametric Test

Source: Own Elaboration 


\section{APPENDIX}

Say if you totally agree or totally disagree with the following statements about tourism and foreign residents in Alfaz del Pi, where 1= I totally disagree and 7= I totally agree. N= Don't know/No answer

Tourism in Alfaz del Pi brings new business and work opportunities

$1234567 \mathrm{~N}$

The presence of foreign residents in Alfaz del Pi means new business and work

opportunities

Tourism takes up all the best places in Alfaz del Pi

$1234567 \mathrm{~N}$

Foreign residents take up all the best places in Alfaz del Pi

$1234567 \mathrm{~N}$

The relationship between tourists and the Spanish inhabitants of Alfaz del Pi is

good

The relationship between foreign residents and the Spanish inhabitants of Alfaz del $1234567 \mathrm{~N}$

Pi is good

Tourism has made housing prices increase in Alfaz del Pi

$1234567 \mathrm{~N}$

Foreign residents have made housing prices increase in Alfaz del Pi

$1234567 \mathrm{~N}$

Were it not for tourism, Alfaz del Pi would have financial difficulties

$1234567 \mathrm{~N}$

Were it not for foreign residents, Alfaz del Pi would have financial difficulties

$1234567 \mathrm{~N}$

Tourists in Alfaz del Pi are generally educated people

Foreign residents in Alfaz del Pi are generally educated people

$1234567 \mathrm{~N}$

$1234567 \mathrm{~N}$

Tourism provides Alfaz del Pi with an international ambiance

$1234567 \mathrm{~N}$

Foreign residents provide Alfaz del Pi with an international ambiance

$1234567 \mathrm{~N}$

On the whole, living in Alfaz del Pi is satisfactory for me

$1234567 \mathrm{~N}$ 